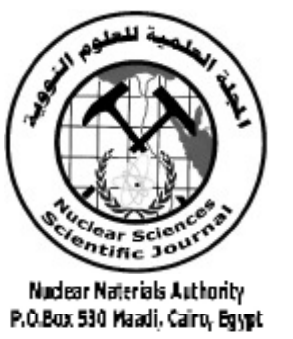

ISSN 2314-5609

Nuclear Sciences Scientific Journal vol. 3, p $85-106$

2014

\title{
GEOLOGY, GEOCHEMISTRY AND RADIOACTIVITY OF GABAL HAMRAT AL JIRJAB AREA, ESH EL MELAHA RANGE, NORTH EASTERN DESERT, EGYPT
}

\author{
MOHAMED A. WETAIT; ABDELAZEIM M. MEHANNA ;LOTFY M. NOSSAIR'; \\ ABDELAZIZ A. W. MHAMED ${ }^{1}$; SALAH S. EL BALAKSSY ${ }^{1}$ and ABDELBASET M. \\ ABD EL-HADI ${ }^{1}$

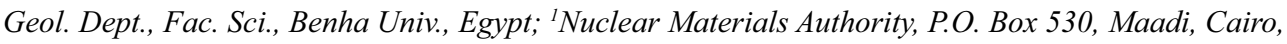 \\ Egypt
}

\begin{abstract}
Gabal Hamrat Al Jirjab area is located in the northern part of Esh El Melaha range, north Eastern Desert. The area is covered mainly by Dokhan volcanic rocks (andesite, dacite and their pyroclastics) intruded by alkali feldspar granites of G. Hamrat Al Jirjab with some dyke swarms of various composition, felsic dykes (granophyres and rhyolite), intermediate dykes (andesite) and basic dykes (dolerite).

The studied Dokhan volcanics are considered as medium-K rocks originated from calc-alkaline magma in island arc to active continental margin environment. On the other hand, the studied granites are classified as alkali feldspar granites and considered as I-type, originated from peraluminous calc-alkaline highly fractionated magma. They are post-orogenic and formed under an extensional regime suggesting crystallization during relaxation stage that following collision. They are intruded in a crust of thickness $>30$ $\mathrm{Km}$ and crystallized at temperature $<800^{\circ} \mathrm{C}$.

Alkali feldspar granites of G. Hamrat Al Jirjab can be described as uraniferous granite. The average values (16 ppm eU and $32 \mathrm{ppm}$ eTh) are attributed to the presence of $U$ and Th bearing accessory minerals namely; thorite, uranothorite, monazite, zircon, fluorite and allanite.

Stream sediments of G. Hamrat Al Jirjab area exhibit mixture of detritus components, represented by pebble, granules, sand and sizes less than very coarse silt. These sediments are considered the natural trap for the accessory and some radioactive minerals for the surrounding country rocks.
\end{abstract}




\section{جيولوجية وجيوكيميائية و إثعاعية منطقة جبل حمرة الجرجاب ، سلسلة عش الملاحة ،

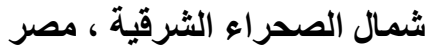

محمد أحمد وتيت ، عبدالعظيم محمود مهنا ، لطفى مصطفى نصير ، عبدالعزيز عبدالو ارث محمد ، صلاح صبحى البلاقصى و عبدالباسط محمد عبدالهادى ، عبرى

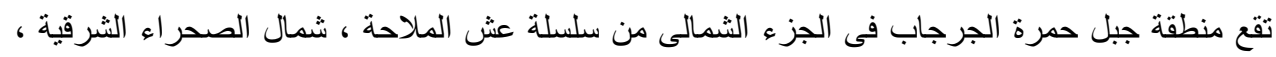

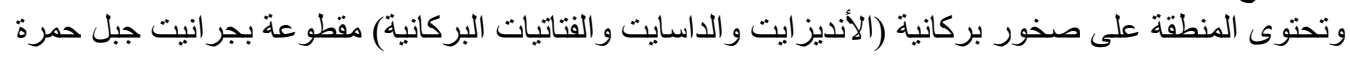

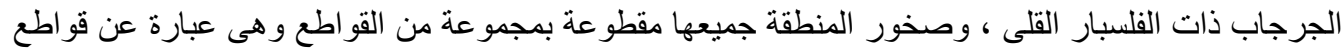

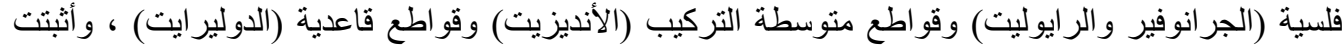

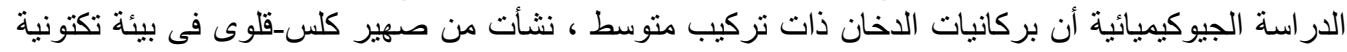

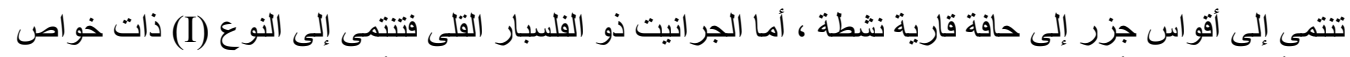

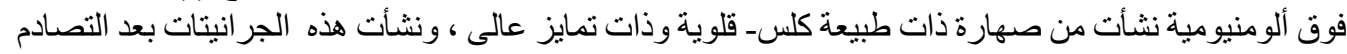

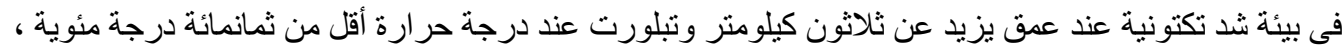

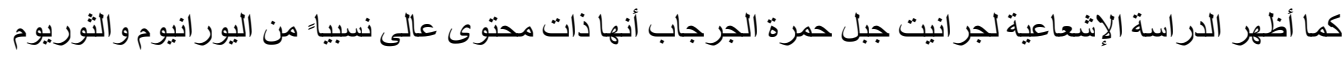

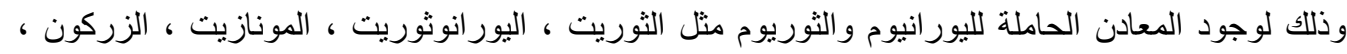

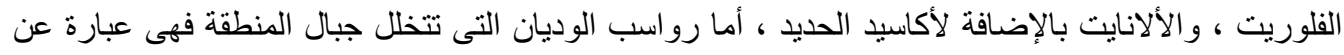

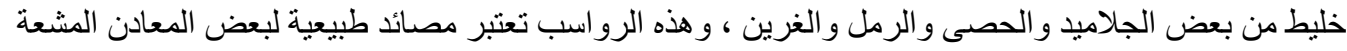

